\title{
NINETEENTH CENTURY SOCIETAL REACTIONS TO JUVENILE DELINOUENTS: PRELIMINARY NOTES FOR A NATURAL HISTORY ${ }^{1}$
}

Philip L. Reichel

Kansas State University

Mid-American Review of Sociology, 1979, Vol. IV, No. 2:39-54

Using the hypothetical natural history model suggested by Spector and Kitsuse, this paper reviews societal reactions to problem children in the nineteenth century. Humanitarian and class interests are highlighted in describing how those reactions may have been propelled through the stages of a natural history. The author concludes that continued research on societal reactions to juvenile delinquents will enable construction of a natural history for those reactions.

Prior to the 1960s, interest in delinquency primarily emphasized the activities of the juvenile rather than the responses by society. Such a position prevented obtaining a complete understanding of the social problem we call juvenile delinquency. The changing nature of societal norms means " $[t]$ he only way we can really know the meaning of juvenile delinquency is to discover how society over a period of time has attempted to define and combat it" (Mennel, 1973:xii).

The works of Hagan and Leon (1977), Hawes (1971), Kittrie (1971), Mennel (1973), Platt (1969), and Rothman (1971) are examples of scholarship that appreciates the importance of understanding the history of societal reactions to juveniles. However, use of a historical perspective is often undertaken without a model for analysis. The result tends to be little more than a journalistic report or "history." Such accounts are needed, but it is also desirable to go beyond the portrait of the individual example and develop a collective portrait of the type (see Spector and Kitsuse, 1977:135). This process involves the construction of "natural history." The present paper is an attempt to begin such a construction for societal reactions to juvenile delinquents.

The literature on the natural history approach includes the work of Fuller and Myers (1941) who viewed social problems as going through the states of awareness, policy formation, and 
reform. An excellent review of the natural history literature since 1940 is provided by Mauss (1975:57-59) and need not be reiterated here. It is sufficient to note that works since that of Fuller and Myers have used their basic idea but emphasize and expand various points according to the author's own interest (e.g., Mauss, 1975; Spector and Kitsuse, 1973, 1977; Ross and Staines, 1972; Reissman, 1972; and Blumer, 1971).

\section{THE NATURAL HISTORY}

For Kitsuse the "notion of a natural history of social problems emphasizes the definitional activities of groups and how those activities constrain and shape the development of the claims-making process that we call social problems" (1977:1, emphasis in original). When considering the social problem of delinquency, we must first determine which individuals (groups) have provided our definitions. Then, we look at what the groups say, to whom they say it, what is done about what they say, etc. To some extent Platt (1969) has done this for the development of the juvenile court. The analysis he performs is not (nor was it meant to be) a natural history. However, secondary analysis of his data could help yield an empirically derived natural history (see Spector and Kitsuse, 1977:141). That is also true of Pfohl's (1977) study of social forces giving rise to the labeling of child beating as deviant. Although not strictly a natural history, Pfohl does present his argument in a manner conducive to a natural history analysis.

Research also exists on societal reactions to juveniles prior to the creation of the juvenile court in 1899. As with Platt (1969) and Pfohl (1977), these studies were not attempts to determine a natural history. They do, however, offer information useful in constructing a natural history.

This paper is an attempt to identify, in the existing literature, information relevant to a natural history of nineteenth century societal reactions to juvenile delinquents. This should be seen as only a preliminary step in establishing such a history. Nevertheless, a natural history model can be used to present the material. For present purposes, the model suggested by Spector and Kitsuse $(1973,1977)$ seems appropriate.
Spector and Kitsuse's natural history model involves four stages. The stages can be summarized as follows:

Stage one [Awareness] : The attempts by some group(s) to assert the existence of some condition, define it as offensive, harmful, and otherwise undesirable, to publicize the assertions and stimulate controversy and to create a public or political issue over the matter.

Stage Two [Official Recognition]: The recognition by some official organization, agency, or institution of the group(s) legitimate standing. This may lead to an official investigation of the matter, proposals for reform, and the establishment of an agency to respond to those claims and demands.

Stage Three [Dissatisfaction]: The re-emergence of claims and demands by the group(s), expressing dissatisfaction with the established procedures for dealing with the imputed conditions, the bureaucratic handling of complaints, and the failure to generate a condition of trust and confidence in the procedures as sympathtic to the complaints, etc.

Stage Four [Creating Alternatives]: The rejection by complainant group(s) of the response or lack of response of the agency or institution to their claims and demands, and the development of activities to create alternative, parallel, or counter institutions as responses to the established procedures (Spector and Kitsuse, 1973:147).

This study will analyze the origin and eventual changes in nineteenth century societal reactions to juvenile delinquents. More specifically, it will address the moral and class interests relevant to the early nineteenth century development of reformatories for delinquent children. A juvenile delinquent at that time was "a young person (under 21) who had broken the law, or who wandered about the streets, neither in school nor at work and who obviously lacked a 'good' home and family" (Hawes, 1971:32). This definition is inexact since the law defining delinquency and 
creating a juvenile court did not arrive until 1899. The child-care institutions reflected the vagueness in their admissions policies. Rothman described the policies as "a catalogue of practically every misfortune that could befall a minor" (1971:209).

\section{Stage One: Awareness}

Spector and Kitsuse suggest social problem activity begins with actions of a complaining group. The group may be either "moral crusaders" or "interest groups" (1973:148). Historical studies have concentrated on groups and individuals typically categorized as moral crusaders. Nineteenth century philanthropists exemplify such individuals when analyzing societal reaction toward juvenile delinquents of that century. Mennel (1973:4-5) describes those philanthropists as being, in general, descendants of established families and prosperous members of the merchant or professional classes. Further, they were conservative reformers who defined themselves as God's Elect and felt duty bound to develop charitable organizations in His name.

Although several groups and individuals played a definite role in this awareness stage (see Hawes, 1971:33) one particular organization had overriding influence. That was the Society for the Prevention of Pauperism which was formed in 1817 in New York City. Two of the leaders of the SPP, John Griscom and Thomas Eddy, are especially noted for their interest in the moral health of the community. The poor and deviant became objects of their concern and their moral stewardship. Their intent was to regulate community morality by example and through benevolent activities (Krisberg and Austin, 1978:14). Such concerns required attention to a variety of social evils but Griscom, Eddy, and the SPP were most successful in altering societal response to juvenile delinquents. Members of the SPP found the prevailing practice of placing children in adult jails and workhouses to be very undesirable. The abominable conditions of those places intensified the disgrace. In 1822 the SPP issued its Report on the Penitentiary System in the United States which called for the erection of new prisons for juvenile offenders. The youth confined in the new prisons were "to be placed under a course of discipline, severe and unchanging, but alike calculated to subdue and conciliate. A system should be adopted that would provide a mental and moral regimen" (Mennel, 1973:11).

Because of their social status it is unlikely SPP members were directly affected by the undesirable conditions they saw. Apparently they were concerned instead for humanitarian reasons. On that basis it seems appropriate to consider the SPP members as falling in Spector and Kitsuse's "moral crusaders" category. However, some historical reports suggest the charitable work of the philanthropists was actually undertaken for their own protection and economic advantage. If that is true, the possibility of categorizing SPP members under "interest groups" must be considered. Discussion will now address that possibility.

Rothman (1971) has provided a seminal work on the creation, by Americans, of institutions for deviant and dependent members of the community. A central point of that work suggests Jacksonian era Americans came to view poverty differently than American colonists. The colonists had accepted poverty as normal and made little effort to eliminate it. Their successors, however, saw dependency as abnormal and moved to confront it (Rothman, 1971:161). The new view of the poor was occasioned by such things as breakdown of traditional mechanisms of social control (Rothman, 1971:178) and fear of social unrest and chaos (Mennel, 1973:6-11). The growth of a visible class of paupers and the accompanying increases in crime disturbed those in power (Hawes, 1971:33). The elite could no longer enforce their policies from positions in church and government. They believed maintenance of their authority now depended upon founding a host of benevolent societies (Mennel, 1973:7). We return then to the origin of such organizations as the SPP. From this perspective, however, we see the SPP members as acting less on humanitarian grounds and more in attempts to perpetuate class position. That is, the philanthropists organized against the new enemy-pauperism. They did so not as "moral crusaders," but as interest groups.

A desire to perpetuate class position was not the only group interest operating at this awareness stage. Krisberg and Austin (1978:14) believe nineteenth century philanthropy was aimed at 
Mid-American Review of Sociology

reestablishing social order while preserving the existing property relationships. In a similar manner Bremner (1960), in his work on American philanthropy, shows how our history has provided temptation to misuse philanthropic slogans for, among other things, economic ends. Such arguments are made more specific by Quinney (1977:36-37) who has stated: "All social life in capitalist society, including everything associated with crime... must be understood in terms of the economic conditions of production and the struggle between classes produced by these conditions."

If Krisberg and Austin, Bremner, and Quinney are correct, we should expect the SPP members to have supported societal reactions toward juvenile delinquents (a symptom of pauperism), which in some way reflected the demands of the early to midnineteenth century labor market. That topic is, however, more appropriate for the second stage of the natural history now being proposed. Suffice it to note here that interests centering on maintenance of economic privilege may also have been present when philanthropists were organizing such groups as the SPP.

Where are we then in our quest to categorize the complaining group who is presented as beginning the social problem activity of present concern? On the one hand we find that the members of the SPP (and other philanthropists) were men whose sensibilities were offended by the prevailing treatment of juvenile delinquents. Their attempts to change the societal responses to juvenile delinquents must certainly have reflected intentions which reasonable men would see as "moral crusades." However, the historians tell us these same men were also fearful of the growing class of pau-. pers. Since adult paupers and criminals were felt to have been delinquent in their youth, it was determined the best way to eliminate pauperism was to reform the delinquent (Hawes, 1971: 33). It seems reasonable to conclude that members of the SPP were acting on the basis of class interests. That is, they initiated social problem activity to perpetuate class position. Finally, some authors have suggested that any kind of punitive societal reaction will be an expression of certain economic concerns. Although evidence has not yet been presented in this paper to support that position, it is desirable to suggest it as another
Nineteenth Century Societal Reactions

indication of social problem activity being initiated by "interest groups."

On the basis of the above information it seems unwise to follow Spector and Kitsuse's suggestion that the complaining group initiating social problem activity must be either moral crusaders or interest groups. Instead, for the present instance, the complaining group must be seen as having both moral crusading and interest group aspects. Regarding the latter, those interests are said to be perpetuation of class position and perpetuation of economic privilege. We should not cynically suggest that moral crusaders simply used humanitarian arguments as fronts for status quo maintaining programs. Rather, it must be argued that their initial concerns and the eventual official and public acceptance of their programs were aided by their appropriate "fit" with the stratification and economic systems.

As the SPP members were wealthy and influential men of the community they did not have to be overly concerned with the problems of pressing their claims or gaining sympathy and recognition for their complaints. They were able to appeal to humanitarian considerations in a manifest way and class considerations in a latent (if not covert) manner.

At this point we move to the next stage of the natural history. Awareness of the problem was achieved and formal reaction was forthcoming.

\section{Stage Two: Official Recognition}

On January 1, 1825 the New York House of Refuge opened under the management of the Society for the Reformation of Juvenile Delinquents, as the SPP came to be called. This first institution specifically for juvenile delinquents ${ }^{2}$ reflects activity of Stage Two. The influential SPP and the more official Common Council of New York City had worked together and now realized the fruits of their labors (Hawes, 1971:33-40). The SPP, as a voluntary association, brought public attention to juvenile delinquency. When the Common Council entered the situation it became an instance of "official recognition." Boston followed New York's lead in 1826, and Philadelphia in 1828. These three 


\section{Mid-American Review of Sociology}

institutions defined institutional treatment of juvenile delinquents for a quarter century (Mennel, 1973:4).

Spector and Kitsuse note that for a social problem to continue to exist beyond the point of simple official recognition, an in asserted (1973:154). The creation of the New York City, Boston, and Philadelphia facilities met this requirement. In order to ind the evolutionary route beyond this it is necessary to review the manner in which the houses of refuge operated.

As indicated above this paper takes the position that success of the SPP and similar groups rested on the dual nature of their ideology. On the one hand they appealed to humanitarian condeology. On the one hand an group interests. As Platt states:

The child-saving movement was not simply a humanistic enterine classes against the established order. On the contrary, its impetus came primarily from the middle and upper classes who were instrumental in devising new forms of upper classes who were instrumental in devising in socialy $(1974: 368-369)$.

To this we add the suggestion that the "new forms of social control" also provided for perpetuation of class privileges through exploitation of labor. Support for such an argument has a long history. Sellin, for example, noted the aim of punishment as (1) in $596 \mathrm{AD}$ as being " "to ensure by every means the control of the lower classes' "' (1967: 18) ${ }^{3}$ Sincen as being committed by the vulgar form of punishment should be that applied earlier classes, the form of punis people-the slaves. In 1938, Radbruch to the very lowest layer of people-the slaves. In 1938, Radbruch argued that "as the structure of Germanic society changed over the centuries, punishments originally reserved for those in bondage and ultimately on offenders regardless of their social status" (Sellin, 1976 :viii).

to how corporal and capital punishment reflected slave punishment origins. J. Thorsten

\section{Nineteenth Century Societal Reaction}

Sellin $(1967,1976)$ was intrigued by this argument. He expanded it by suggesting that even penal imprisonment reflects an aspect of slavery-penal servitude.

Sellin notes that imprisonment and hard labor were originally applied as punishment to slaves. When France of the mid-fifteenth century found the supply of free and slave labor on their galley fleets dwindling, it sent beggars and vagrants to fill the galley. Later, felons who had earned capital or corporal punishment were added (Sellin, 1967:19). During the reforms of the late eighteenth and early nineteenth centuries, American states built penitentiaries for serious offenders and provided by law that the prisoners confined "should perform labor of the most harsh and servile kind" (Sellin, 1967:21). On the basis of these arguments it seems desirable to consider the possibility of specific economic interests as orienting societal reactions to juvenile delinquents.

Hawes $(1971: 42-47)$ notes that punishment at the New York House of Refuge included use of the ball and chain, handcuffs, leg irons, and whipping (cf. slave punishments). Additionally, juveniles were to be engaged in work every day of the year (save Sundays) or to be punished for refusing to work. Joseph Curtis, first superintendent of the New York House of Refuge, set up a factory for straw hats and baskets so the children would develop habits of industry (Pickett, 1969:75). The primary mode of labor, however, was the contract or lease system. ${ }^{4}$ Essentially the child was let out to contractors who paid the institution for the child's labor (Hawes, 1971:49). Also, an indenture system was quickly developed by Superintendent Curtis. The first request for indenture came from a sea captain followed by a request from a farmer. Other requests more obviously reflected aspects of slavery. Pickett, for example, notes an early request from a judge for a "black girl" to serve in his family (1969:76). Placement at sea or on a farm became, however, the typical assignments for indentured children (Pickett, 1969:76; and Hawes, 1971:50).

Spector and Kitsuse suggest Stage Two is complete when complaints about the condition become domesticated and routinized by an agency which develops a vested interest in doing something about the complaints, though not necessarily dealing with the conditions from which the complaints arose (1973:154). 
The new facilities for juveniles operated from 1825 until the midnineteenth century in just this manner. Specifically, complaints from the philanthropists regarding the harshness of corporal and capital punishment (overt complaints), the need for protection from the dangerous classes (implied complaints), and the desire for cheap labor (covert complaints) came to be handled by the houses of refuge.

\section{Stage Three: Dissatisfaction}

The procedures established in Stage Two, regardless of intent, may be misconceived or inappropriate to the claims and demands they were designed to handle (Spector and Kitsuse, 1973:154). As a result, the "assertions about the inadequacy, inefficacy, or injustice of the procedures may themselves become the conditions around which new social problems are organized" (Spector and Kitsuse, 1973:155). The distinguishing aspect of Stage Three is that claims are not concerned directly with the imported condition asserted in Stage One but instead with the organization's procedures and methods of dealing with their clients and their complaints.

For societal reactions to juveniles, Stage Three seems to have begun around 1850. At this time, new "child-saving" organizations began condemning the houses of refuge. Like their counterparts twenty-five years earlier, these organizations had humanitarian overt arguments. They believed the family, not the institution, was the best reform school. The arguments were best exemplified by the work of Charles Loring Brace whom Hawes (1971:87) believes was the most important American working with juvenile delinquents in the nineteenth century. Brace was General Secretary of the Children's Aid Society which was a philanthropic organization attempting to help the juvenile vagrants of New York City. Formed in 1853, the CAS quickly helped to open industrial schools and lodging houses for the boys and girls of New York (Hawes, 1971:93-97). ${ }^{5}$ Its most important project, however, was the "placing-out" system wherein city children were apprenticed out to western farm families.

The placing-out system best identifies Stage Three of the natural history. The system was a response to the dissatisfaction regarding the procedures of the houses of refuge. The facilities established for juvenile delinquents were believed to have overlooked the significance of the family in transmitting the norm and values of society (Hawes, 1971:98). Brace's system differed from the apprenticeship system of the houses of refuge because the latter's western farmers took children as cheap labor (according to Brace) while under Brace they would be taken as members of the family (Hawes, 1971:100). After the children arrived at the location they were paraded and presented to townspeople. Later in the day, the families went to a store to pick out whom they wanted (Mennel, 1973:39). The first party from the CAS was sent out in 1854 and public support enabled the system to remain strong until its decline in the $1880 \mathrm{~s}$

In addition to the humanitarian arguments, there were economic considerations which must surely have played a role in the success (and later decline) $)^{6}$ of the placing-out system. Mennel $(1973: 38)$ believes the economic aspect was reflected in the anxieties of local merchants who believed they were threatened by the children of the dangerous classes, as well as the hordes of aggressive young clerks seeking wealth and status. Although Brace believed his system was non-exploitative, the realities of "transportation" and "slave markets" seem only thinly veiled.

A main feature of Stage Three involves a switch from claims about conditions to claims about procedures (Spector and Kitsuse, 1973:155). The present analysis utilizes the CAS to exemplify how this was occurring in the 1850s. The next historical step must proceed from this dissatisfaction with procedures to the development of alternatives.

\section{Stage Four: Creating Alternatives}

"A new stage in the development of social problems occurs when groups base their activities on the contention that it is no longer possible to 'work within the system" " (Spector and Kitsuse, 1973:156). Their response will typically take one of two forms:

(1) the creation of alternative institutions as a means of developing a social and political base for radically changing the existing 
procedures or (2) disaffiliation and withdrawal from the institutional system to create alternative institutions as limited solutions for group members (1973:156-157).

Spector and Kitsuse characterize the first as value-oriented and the second as interest-oriented social problems. For consistency with the terminology of this paper, the first will be called humanitarian and the second economic. The existing literature suggests societal reactions followed the humanitarian path. This is especially evident when considering the creation of that alternative institution called the juvenile court.

"The law which established the juvenile court... provided for a new and unique institution" (Hawes, 1971:159). As the last nineteenth century innovation in the care of troubled children, the juvenile court marked the end of the essentially penal societal response to juveniles (Hawes, 1971:168-170). The stage was set for "scientific" responses which would provide for "treatment" of the juvenile. The individuals and groups responsible for this reorientation of our definitions of social problems have been called the child-savers. Their activities have been well documented (e.g., Platt, 1969; Kittrie, 1971:108), and further review here is not appropriate. It is sufficient to note that societal responses to the social problem of juvenile delinquency ended the nineteenth century at Stage Four. That is, humanitarian (value-oriented) groups expressed their inability to work within the system by establishing the juvenile court as an alternative institution.

At this point it is necessary to direct the reader's attention to an easily overlooked aspect of a natural history. The four stages (or whatever number used) should not be viewed as definitive statements of singular events. Stage One is not the point at which the social problem of concern first occurred or even was first noticed. Instead, it must be seen as merely the point at which discussion is commenced. In the same manner, Stage Four does not necessarily indicate its completion.

The reader has surely noted that within this review are indications of other natural histories operating concurrently, just beginning, or finally coming to an end. As America entered the twentieth century, societal reactions to juvenile delinquents continued to be influenced by social definitions regarding child labor, the labor market, labor unions, ${ }^{7}$ child rearing, education, etc. The complexity of the entire structure cannot be overlooked. The attempt here is merely to enable better understanding of that complexity through analysis of one of its components. Hopefully that analysis has shown how both humanitarian and class interests interplayed to affect nineteenth century social definitions and societal reactions to juvenile delinquents. Further, it is implied that these interests have operated in this century to provide continuing changes in social definitions and institutional responses to those definitions.

\section{SUMMARY AND CONCLUSIONS}

As noted at the beginning, this paper is a preliminary to development of a natural history. Construction of a natural history requires many more examples, and analysis in greater depth, than is offered here. Recognizing this should not, however, require dismissal of all but the most herculean efforts as contributions to knowledge.

This paper (as a non-herculean effort) has attempted to apply a natural history model to a secondary analysis of societal reactions to juvenile delinquents. The purpose is to determine the likelihood of establishing a natural history of those reactions. The conclusion of this paper is that sufficient data exists to support the hypothesized stage activities provided by Spector and Kitsuse. An important modification of the Spector-Kitsuse model was, however, noted at Stage One. Rather than categorizing the complaining individuals initiating social problem activity as moral crusaders or interest groups, it was deemed necessary to see them as having both concerns. A clarification of the Spector-Kitsuse model was noted at Stage Four. Casual reading of natural history models may leave the student with the impression that one can pinpoint the beginning and ending of social problem activity. The present analysis suggests, however, that natural histories must be seen as a study of one component of an ongoing process. ${ }^{8}$

In sum, the foregoing analysis should not be seen as confirmation of the Spector-Kitsuse model. Nor does it mean a natural 


\section{Mid-American Review of Sociology}

history has been delimited. It does mean that continued research on societal reactions to juvenile delinquents is likely to result in identification of a natural history of those reactions.

\section{NOTES}

1. Malcom Spector, John Kitsuse, Wayne Rohrer, and Joann Hamick were kind enough to criticize earlier drafts of this paper. Although each may still have his or her disagreements with the final version, their interest in this project was greatly appreciated.

2. Some children and young persons have been received into such places as the Amsterdam House of Correction, the Hospice de St. Michael in Rome, and the House of Bridewell (Elizabethan London), but such practices were the exception (Mennel, 1973:xx-xxi; and Goldfarb and Singer, 1973:52)

3. In the following discussion the reader will note references to control of the lower classes. This is a socio-political issue that probably has equal (some would say greater) importance with humanitarian and economic interests. However, for purposes of this paper, control of the lower classes will be subsumed under economic considerations.

4. Technically the contract system and the lease system differed but the present discussion will consider them as essentially similar. For the distinctions see Sutherland and Cressey (1974:559-569).

5. The industrial schools could also be analyzed from an economic perspective by noting the work ethic philosophy being expressed by the officials and supposedly ingrained in the juveniles. Twentieth century industrial schools and vocational programs reflect the continuance of this orientation.

6. There were certainly many reasons for its decline, but one of direct economic interest is pointed out by Mennel (1973:62) who notes that the 1880 s was the decade of substantial decline in the agricultural labor market. This is an interesting comment given Brace's denial of any exploitative interests on the part of western farmers participating in the placing-out system.

7. Sutherland and Cressey (1974:563) and Burns (1975:510) discuss the role of labor unions in forcing change in prison labor system.

8. Although this point is not specifically stated in the Spector-Kitsuse model, Spector (1977) has indicated agreement that the problem does not start with Stage One nor end with Stage Four.

\section{Nineteenth Century Societal Reactions}

\section{REFERENCES}

Blumer, Herbert

1971 "Social problems as collective behavior." Social Problems 18 298-306.

Bremner, Robert

1960 American Philanthropy. Chicago: University of Chicago Press. Burns, Henry Jr.

1975 Corrections Organization and Administration. St. Paul: West. Fuller, Richard and Richard Myers

1941 "The natural history of a social problem." American Sociological Review 6:320-330.

Goldfarb, Ronald and Linda Singer

1973 After Conviction. New York: Simon and Schuster.

Hagan, John and Jeffrey Leon

1977 "Rediscovering delinquency: social history, political ideology and the sociology of law." American Sociological Review 42:587-598.

Hawes, Joseph M.

1971 Children in Urban Society: Juvenile Delinquency in Nineteenth Century America. New York: Oxford University Press. Kittrie, Nicholas $\mathrm{N}$.

1971 The Right to be Different. New York: Penguin Books.

Kitsuse, John

1971 Personal Letter. November 12, 1977.

Krisberg, Barry and James Austin

1978 The Children of Ishmael: Critical Perspectives on Juvenile Justice. Palo Alto: Mayfield.

Mauss, Armand I.

1975 Social Problems as Social Movements. New York: Lippincott. Mennel, Robert

1973 Thorns and Thistles: Juvenile Delinquents in the United States, 1815-1857. Syracuse, N.Y.: Syracuse University Press.

Pfohl, Stephen

1977 "The 'discovery' of child abuse." Social Problems 24:310-323. Pickett, Robert S.

1969 House of Refuge: Origins of Juvenile Reform in New York State. Syracuse, N.Y.: Syracuse University Press.

Platt, Anthony

1969 The Child Savers. Chicago: University of Chicago Press.

1974 "The triumph of benevolence: the origins of the juvenile justice system in the United States." Pp. 356-389 in Richard Quinney (ed.), Criminal Justice in America. Boston: Little Brown. 
Mid-American Review of Sociology

Quinney, Richard

1977 Class, State, and Crime: On the Theory and Practice of Criminal Justice. New York: David McKay.

Reissman, Leonard

1972 "The solution cycle of social problems." The American Sociologist 7:7-9.

Ross, Robert and Graham L. Staines

1972 "The politics of analyzing social problems." Social Problems $20: 18-40$.

Rothman, David J.

1971 The Discovery of the Asylum. Boston: Little Brown.

Sellin, J. Thorsten

1967 "A look at prison history." Federal Probation 31:18-23.

1967 Slavery and the Penal System. New York: Elsevier. Spector, Malcom

1977 Personal letter. December 6, 1977.

Spector, Malcom and John I. Kitsuse

1973 "Social problems: a re-formulation." Social Problems 21:145159.

1977 Constructing Social Problems. Menlo Park: Cummings.

Sutherland, Edwin and Donald Cressey

1974 Criminology (9th ed.), New York: Lippincott.

\section{NOTES AND COMMENTS}

\section{END OF IDEOLOGY? A TREND ANALYSIS OF COMMUNIST PARTY STRENGTH IN TEN ADVANCED INDUSTRIAL DEMOCRACIES}

\author{
Michael F. O'Keefe \\ University of Kansas
}

During the early 1960 s, a number of prominent political and social theorists argued that one of the major results of the phenomenal economic growth of Western Europe after World War II was the "deradicalization" of politics. Ideology would cease to be a major factor as the radical parties of the left and right responded to a breakdown in traditional class cleavages to pursue "pragmatic" programs of economic reform. ${ }^{1}$ More recent studies focusing on value changes (Inglehart, 1971) and capital-labor confrontations (Hibbs, 1976) in these countries suggest, however, that ideological politics has not disappeared. This paper examines trends in strength of the communist parties in ten West European nations to determine whether their hypothesized decline as a result of economic development ${ }^{2}$ has occurred.

Communist parties were chosen for the analysis on the basis of two of their characteristics: (1) as revolutionary social movements they require a great deal of commitment from their members (Kriegel, 1972) and are likely to be more susceptible to membership decline if the "new Europe" theorists are correct, and (2) they "remain important agencies for the mobilization of latent discontent and the crystallization of labor-capital cleavages" in advanced industrial societies (Hibbs, 1976:1058).

\section{ECONOMIC DEVELOPMENT AND COMMUNIST PARTY STRENGTH}

Lipset (1960) argued that sustained economic growth and the relative absence of economic crises combined with increased levels of citizen education result in declines in economic insecurity and high levels of citizen political sophistication. This cluster 